\title{
A Critical Analysis of the Impacts and Benefits of Mobile- Telecommunication Sector in Cameroon
}

\author{
Kinga Hellen Kimah
}

Ph.D Research Candidate, Graduate Teaching Assistant (Moniteur), Faculty of Law and Political Science, University of Bamenda, Bamenda, Cameroon

DOI: $10.36348 /$ sijlcj.2020.v03i08.002

| Received: 27.06.2020 | Accepted: 07.07.2020 | Published: 29.08.2020

*Corresponding author: Kinga Hellen Kimah

\section{Abstract}

Mobile telecommunication and information technology is of utmost important in our social life, the economy, business transactions and education among others. Regrettably, the interacting innovations in products, services and technologies with a general convergence or blurring of distinctions between platforms, products and services has created enormous impacts as well as benefits in the mobile telephony sector. This paper therefore, seeks to examine these impacts and benefits of mobile telecommunications sector in Cameroon. In order to attain the above objectives, we employed content analysis in this regard. This paper therefore, conclude with some robust recommendations which if effectively implemented, will go a long way to improve on the mobile telecommunication sector as a result, enhance the digital economy of Cameroon.

Keywords: Mobile-Telecommunication-Analysis-Impacts-Challenges-Sector-Cameroon.

Copyright @ 2020: This is an open-access article distributed under the terms of the Creative Commons Attribution license which permits unrestricted use, distribution, and reproduction in any medium for non-commercial use (NonCommercial, or CC-BY-NC) provided the original author and source are credited.

\section{INTRODUCTION}

The current development of telecommunications in Cameroon is characterised by a number of emerging trends, requiring regulation and deregulation as proper telecommunication market practices. Some appear to be healthy for a sector in search of new models while others are less promising [1]. These emerging trends and challenges arise from particular new technologies that raise new regulatory issues, e.g., Voice over Internet Protocol (VoIP), Internet Protocol Television (IPTV), social networking, e-commerce, cyber security, including public health and environmental considerations [1]. Although the level of corporate use of ICTs in Cameroon is relatively low, user needs continue to grow amongst the population. As such, the most commonly encountered uses of telecommunications are related to the specificities of the domain, such as calls, internet, commercial duties (purchasing and marketing), management duties (administrative and finance) and production duties. An appraisal of the current trends - both pros and cons will help in the determination of appropriate policies, to match the ever changing telecommunications environment.
The Historical Evolution of Mobile Telecommunications Sector

The use of applications depends entirely on the duties of the users - be it an individual or an enterprise. Enterprises with Internet connectivity quite often are involved with e-transactions, such as online banking transactions, mail exchange, and search of content [1]. However, the use of e-transaction applications on legal and tax issues, which are common in other countries as a catalyst for economic development, is relatively low in Cameroon. In the public sector, the financial services (taxation, customs, treasury, salaries, and the budget) are relatively more advanced in ICT usage. In fact, these services are far better equipped than other government services. The oldest and largest state computerised management applications with interregional networks are found in this sector [1]. In the light of this research, some of these issues are worth elucidating.

\section{ICT and Society}

The ICT is both a social and economic enabler. These initiatives reflect the growing acceptance that ICTs offer major transformational opportunities. They can contribute to enhanced productivity, competitiveness, growth, wealth creation, and poverty reduction. They have the potential to catapult us from 
an information society to the next level - that of a knowledge-based society and economy. ICTs provide the means, by which knowledge is developed, stored, aggregated, manipulated and diffused [2]. ICTs can aid sustainable economic development when used appropriately, with the full participation of all stakeholders, especially the developing economies. The intrinsic value of ICTs lies not in easing communications and information, but in enabling growth and development [3].

These opportunities are well known and are not just a developed country phenomenon. ICTs, particularly access to broadband internet, are vital for developing nations as well. The ITU's Build on Broadband project is dedicated to promoting equitable, affordable broadband access to the Internet for all people, regardless of where they live or their financial circumstances. Clearly, ICTs can have an important impact on everyday lives and on general economic activity, but the opportunities only materialize fully to the extent that the regulatory framework, as implemented, supports and fosters both investment in and widespread diffusion of ICTs. Absent these conditions, the full promise of ICTs is unrealised. ICTs offer the prospects of rapid advancements, but if appropriate conditions are not in place, the outcome can be a rapid slide down the digital divide [2].

Cameroon is among the sub-Saharan countries that are making enormous progress in the use of information and communications technologies (ICTs) in the various development sectors, including education. Although private schools introduced ICTs into their curricula in the $1990 \mathrm{~s}$, ICTs were officially introduced into education in 2001. The cyber education project launched since then by the government targets secondary and tertiary education. Major achievements include establishing multimedia resource centres (MRCs) in universities, professional, and technological schools, and some government secondary schools; training monitors to manage MRCs; creating learning platforms; interconnecting the ten state universities across the country, and establishing training units in professional schools and universities, some of which are now operational [4]. This training is most often tailored to individual needs to master the new tools, including the use of mobile telephones.

In the public sector, a lot of effort is being done to use information technology. On the one hand, three projects are being conducted: one by the state finance service, Integrated System for the Management of Public Finances (SIGEFI), another by the state human-resources service, Integrated System for the Computerised Management of State Personnel and Salaries (SIGIPES), and the last by the customs department (SYDONIA), for trans-border customs clearance and tracking of merchandise. Other projects, like the digitalized electoral list, the social security and health systems, and the e-government system are equally on-going [5]. On the other hand, the rate of computer penetration in institutions is low: $66.2 \%$ of institutions have no computer, and only $6.2 \%$ have more than one computer. Consequently, the number of employees having access to a computer at the work place is relatively very low; in most ministries, ICTs are used essentially for office automation. Although the ICT equipment pools are often located within the central services, the external or de-concentrated services still rely on the typewriter. In the meantime, very few institutions are connected to the Internet $(9.2 \%)$ and have a website (10.8\%) [4]. In addition, wide disparities in income and educational levels prevent a large penetration of ICTs devices among the population. Cyber cafés are the chief mode of access for the vast majority of Cameroonian Internet users.

Since 1998, with the introduction of competition in mobile telephony sector, aimed at providing network coverage throughout the country, mobile operators who are profit-driven and very interested to get a return on their investments have found this urban and populous regions more attractive for business. As a result, coverage of the rural areas has been the responsibility of the government of Cameroon, who in an attempt to address this gap launched the Multipurpose Community Telecenters (MCTs) project launched in 2013. This project was designed to bridge the digital divide between the rural and sub-urban areas, often neglected by private operators and the urban areas with infrastructure installed offering affordable telecommunication and ICT services (telephone, fax, photocopying, television, Internet) and postal financial services (money transfer and messaging) [6].

\begin{tabular}{|r|r|r|}
\hline Region & Telecenters & Digital Access Point \\
\hline Adamawa & 11 & 03 \\
\hline Centre & 28 & 05 \\
\hline East & 15 & 06 \\
\hline Far-North & 20 & 08 \\
\hline Littoral & 14 & 05 \\
\hline North & 13 & 06 \\
\hline North West & 10 & 07 \\
\hline West & 21 & 03 \\
\hline South & 29 & 06 \\
\hline South West & 16 & 03 \\
\hline Total & 177 & 52 \\
\hline Grand Total & & 231 \\
\hline
\end{tabular}

\section{Statistics on Telecenters and Digital Centres}

In the latest development, the government of Cameroon decided to modernise the higher education sector by offering a laptop to each student of state or private universities. The first phase of this project is the delivery of 500,000 laptops to students [7]. This action that was taken in July 2016 is to help students to move to the digital world. The access to this new world will for sure help students in carrying out several educational and training activities that will allow them 
to build specific skills and competences and improve existing ones, by incorporating the mobile telephony data use. Moreover, students will have adequate tools and skills to integrate e-learning, e-commerce necessary for the success of the infrastructural layer of the digital economy model. The big challenge here is how to give Internet access to all these students in order to really gain benefit from this government action [8].

Finally, although the audio-visual sector has existed a long time, the liberalisation of the sector has encouraged private initiatives. For instance, private newspapers, radio, and television have small resources for production and distribution. These new media have espoused IT to boost their business and reach a broad audience, resulting in the wide spread of private media on the Internet. However, content and a programme productions industry is still awaited. Generally, the low quantity and quality of national audio-visual production does not allow Cameroon to stand as a major player in the huge global market, with far more than merely economic implications

\section{The move to Digital Economy}

There are abundant evidences whereby technology leapfrogging has been a major contributor to fundamental changes; notably growth in global production and the distribution of intangible goods and services [9]. The Digital Economy is becoming the new bet for economic growth, provoked by technological innovation and network expansion in ICT development in services sectors such as governance, telecommunication, banking, insurance, education, health and agriculture. At this stage, Internet and other ICT components can play an important role to not only foster the existing businesses but also to invent new business models. The integration of ICT in the daily life activities of people in developing countries has inevitably brought them to integrate the digital economy. The digital economy refers to an economy that is based on digital technologies. It can also be perceived as conducting business through markets based on the Internet, World Wide Web and usage of social computing platforms [8]. The use of mobile phones is paramount in this regard.

The implementation of digital economy is grounded on a harmonisation of: the technologies, reflecting the infrastructural development; the policies, to build an appropriate and regulatory environment for the digital economy; the people, as they are related to human capacity and coping with the innovation and response to the new environment; and the strategies, to effectively explore and exploit ubiquitous opportunities provided by the new economy [8]. In Cameroon, the new economy helps architects design buildings and roads, track sales and inventory, get goods from one place to another, execute various trades and banking operations, control manufacturing equipment, provide bills for clients, help diagnose patients, and guide surgeries using computers. Such operations grow slowly and take time to form [10].

The rapid spread of e-applications and digital tools to such diverse areas as manufacturing, transportation, logistics, finance, banking, governance, health, education and even in traditional sectors like agriculture is transforming the economies of developing countries. IT investments raise worker productivity three to five times that of non-IT capital [2]. One sector that has significantly embraced cyber in Cameroon is in the banking. From well-established financial institutions to bourgeoning micro-finance companies, they all utilise IT to proceed in their daily tasks. Where ICT becomes crucial is in money transfer, using the current GSM technology well disseminated across the country; micro-finance companies have developed a prolific and competitive new way of exchanging and making money transactions.

The existing laws, as analysed in the foregoing chapters, adequately regulate the exiting framework on digital economy. At the infrastructural level, the main basis for the development of digital economy is twofold: Energy (electricity) and Telecommunications and ICTs. Unfortunately, Cameroon is not yet part of the Connectivity scorecard, a global ICT index that ranks 52 countries not only on their deployment of ICT infrastructure but also the extent to which governments, businesses and consumers make use of connectivity technologies to enhance social and economic prosperity, so called 'useful connectivity' [8]. This is based on the fact that most Cameroonian businesses are not online.

Therefore, the development of Digital Economy in Cameroon, will aim at ensuring its economic success using Telecommunications and ICTs. One of the actions of the strategy is to avoid digital disruption. The benefits of new technologies can be undercut by digital disruption in the negative use of such technologies [8]. Many other actions are needed to be undertaken. The Digital Economy Fact Book, in its ninth edition, presents a factual basis from which analysis of a given entity in the new economy can start. The indicators are:

- The Growth of the Internet: host computers and domains, online population, number of Websites, ISP, etc.;

- The Hardware Sector: PC sales, cell phones, smartphones, data storage, gaming hardware, etc.;

- The Communications Sector: telephone subscription, wireless industry, VoIP, email, etc.;

- The Digital Media: TV, Internet Video, Music, Radio, Gaming, Online News, Blogging, Social Networking, etc.;

- The Electronic Commerce: Internet advertising, online finance, online travel, 
online health care, and the types of $\mathrm{e}-$ commerce systems (B2C, B2B, etc.).

- The Threats to the Digital Economy: malicious software, spam, phishing, identity theft, piracy, privacy violation, etc.

- The Worldwide Digital Economy: funding for new ideas, mergers and acquisitions, outsourcing and off-shoring, IT spending, etc [11].

\section{The Impacts of Mobile Telecommunication Sector}

The safety of telecommunications (telecoms) infrastructure, is a call for concern, especially, when the mast are mounted close to buildings. The explosive growth in the Telecommunication industry in Cameroon, has led to an increase in teledensity and the number of connected devices. With thousands of Base Transceiver Stations (BTS) and Switching System spread across the country, the risk is real, as radio waves are all around us, from the sun, mobile phones, broadcast towers, radars, Wi-Fi routers, satellites, etc. It means that telecommunications is by electromagnetic waves. An electromagnetic field consists of waves of electric and magnetic energy moving together through space. Often the term "electromagnetic field" or EMF is used to indicate the presence of electromagnetic radiation.

\section{Environmental protection standards of Mobile Communications Networks}

Information and Communication Technologies (ICTs), such as satellites, mobile phones or the Internet, are capable of playing a key role in addressing the global challenges of climate change and sustainable development [12]. The mobile industry is a relatively low energy intensity industry, contributing much more to the economy than its proportion of national energy usage [13]. The general tendency is that energy use is growing as subscriber numbers increase [14]. In fact, more than $80 \%$ of a typical mobile network operator's energy requirements are associated with operating the network [5]. The typical annual $\mathrm{CO}_{2}$ emissions per average GSM subscriber is now about $25 \mathrm{~kg} \mathrm{CO}_{2}$, which equates to the same emissions created by driving an average European car on the motorway for around one hour [16]. This is particularly driven by the unreliable grid electricity in areas across the country. A 2007 trial in Namibia showed the feasibility of a combined wind and solar system to power a base station with a return on investment period of three years. It was estimated that such a solution would save roughly $4,580 \mathrm{~kg} \mathrm{CO}$ annually versus grid electricity and an additional $649 \mathrm{~kg}$ of $\mathrm{CO}_{2}$ annually by removing backup Diesel Generators
[13]. The focus is on ICT greenhouse gas (GHG) emissions and the emissions savings created through green mobile telecommunications applications and in other industry sectors. Overall, it therefore means that network optimisation upgrades currently can reduce energy consumption by $44 \%$ and solar-powered base stations could reduce carbon emissions by $80 \%$. The expected adoption of these measures by 2020 would lead to the avoidance of almost $60 \mathrm{MtCO}_{2} \mathrm{e}^{5}$ in 2020 [13]. Further, electricity grids must be modernised to reflect the energy demands of the 21 st century. A smart grid adds communications and thus monitoring, analysis and control capabilities to the electricity grid; increasing its efficiency and reliability, reducing its energy consumption, and minimizing its GHG emissions [12].

There is therefore the need for mobile industry to continue to look for ways to reduce energy needs. Air conditioning is being replaced by fans or passive air flows whenever possible.

\section{Placement of Telecommunication Masts and Towers}

The general position is that the type of radiation that is harmful is ionizing radiation, which carries large amount of energy which is enough to ionize atoms and molecules, and break chemical bonds [17]. Other sources include X-rays from medical radiography. On its part, the Non-ionizing Radiation is the lower-energy, longer-wavelength part of the spectrum including visible light, infrared light, microwaves, and radio waves is non-ionizing; its main effect when interacting with tissue is heating. This type of radiation only damages cells if the intensity is high enough to cause excessive heating [18]. In fact, the common sources of this radiation exposure are FM/AM Radio Stations, TV transmissions, Wireless Networks, Mobile Phones etc. The operating frequency for Wi-Fi is $2.4-2.5 \mathrm{GHz}$, with radiated power of $0.010-0.10$ watt. That for Mobile Phones' operating frequency is GSM-1800, CDMA GSM-900, with radiated power of 1 watt [18].

The International Commission on NonIonising Radiation Protection (ICNIRP), issues guidelines on the basis of the current scientific knowledge on Non-Ionising Radiation protection. Based on established biological and health effects, it provides estimation for occupational and general public exposure. Most countries draw on ICNIRP guideline for their own national standards. According to the ICNIRP guideline, mobile phone, base station exposure is as follows:

\begin{tabular}{|l|l|l|l|}
\hline Mobile Phone/Base Station [Unit Power Density (W/m2)] \\
\hline Frequency & GSM 900MHz & GSM 1800MHz & WCDMA 2100MHz \\
\hline Public Exposure Limits & 4.5 & 9.0 & 10.0 \\
\hline Occupational Exposure Limits & 22.5 & 45.0 & 50.0 \\
\hline
\end{tabular}

Source: summary for ICNIRP guideline. 
According to the Nigerian regulation, a typical compliance boundary for a typical base station and antenna (output power is $20 \mathrm{~W}$, antenna gain is $15 \mathrm{dBi}$ ) and considering general public, the area outside about $4 \mathrm{~m}$ diameter around antenna is safe. Actual deployment conditions are as follows: The minimum height for the installation of radio antenna is 24 metres; Minimum distance from base of a telecoms mast to a domicile is 10 metres; ICNIRP Compliance boundary is 4 metres.

The above discussion clearly show that the regulation in Cameroon do not respect the standards under the ICNIRP guideline. On this note, the position of WHO on EMF Radiation from GSM Equipment is that:

'Considering the very low exposure levels and research results collected to date, there is no convincing scientific evidence that the weak $R F$ signals from base stations and wireless networks cause adverse health effects. 'Studies to date provide no indication that environmental exposure to $R F$ fields, such as from base stations, increases the risk of cancer or any other disease [19].'

On this note, it is important to point that radiation emanating from mobile networks within the specified limits is not harmful. Notwithstanding this conclusion, the regulators in Cameroon must be able to conduct practical field measurements of EMF and Electric Field Strength measurements on BTS across the country, pursuance of its regulatory functions in ensuring compliance with acceptable environmental, public health and safety standards. This also includes equipment type approval and BTS site approvals.

\section{Maintenance of towers and management of e-waste} Because of the rapidly progressing telecommunications industry, there is increasing consumption of electrical and electronic equipment (EEE) and a marked increase in electronic waste (ewaste), which, as a result of global mismanagement, has led to negative environmental and health effects, particularly in developing countries [20]. The new Resolution 79 on "The role of telecommunications/ICT in handling and controlling e-waste from telecommunications/ ICT equipment and methods of treating it" was approved at the World Telecommunication Standardization Assembly (WTSA12) in Dubai, November 2012. The Resolution calls upon ITU to strengthen its activities in this arena and to assist ITU Member States in instituting policy frameworks that limit e-waste's negative environmental effects [12].

Recommendation ITU-T L.1000 (Universal power adapter and charger solution for mobile terminals and other hand-held ICT devices) details a universal charger compatible with a variety of consumer electronic devices, reducing waste and improving convenience to users. ITU-T L.1000 will eliminate an estimated 82,000 tons of redundant chargers and at least 13.6 million tons of $\mathrm{CO} 2$ emissions annually.

Many network upgrade contracts now include recycling and take-back provisions for used equipment that may be resold in another market [20]. Optimisation of the physical network through improved planning, minimising the number of actual base stations or using a more effective mix of base station types will also contribute to significant energy savings [13].

\section{Indirect Contributions to Reduce Environmental Impacts}

Mobile communications has the potential to make direct and indirect contributions to reducing the environmental impacts of other industries. For the total ICT sector the potential indirect benefits are estimated to about 5 times the direct benefits [13]. As an example, it has been estimated that the environmental burden of a business round-trip travel between Berkeley and Chicago is 10 to 1,000 times greater than conducting the meeting as a wireless teleconference [13]. Areas of potentially larger contribution include using wireless broadband to improve active load management for more efficient use of alternative energy sources; support for tele-working; using a person's mobile phone to register their presence so that heating or lighting can respond; real-time freight management and dematerialisationreplacing physical items (such as CDs) with digital downloads [13].

\section{Future Networks}

Environmental awareness is one of the fundamental objectives of Future Networks (FNs) with network architects embracing the challenge to reduce FNs' environmental impact. Recommendation ITU-T Y.3021 (Framework of energy saving for future networks) focuses on "Green Future Networks", tackling energy saving within networks to account for rapidly increasing energy consumption brought about by rising numbers of network applications. Energy saving within networks entails network capabilities and operations that systematically and efficiently manage the total energy consumed by network equipment. ITU$\mathrm{T}$ Y.3021 provides a framework to minimize the energy consumption of network facilities such as routers, switches and equipment at the terminating point by means of technologies such as clock gating, sleep mode control, filtering, shaping, smart antenna technologies, lightweight protocol, transmission scheduling and traffic peak shifting [12].

\section{Public Health Considerations}

Health risk surround mobile telephone us, due to mobile phone radiation it produces. Research findings indicate that the use of mobile phones may lead to a number of symptoms such as brain tumours, headache, impaired concentration and memory, and also fatigue, thereby, requiring high regulation. There are worldwide reports about the possible link between 
adverse health effects and mobile phones. Although there is no clear evidence on the adverse physiological effects of electromagnetic fields (EMF) at the levels used by mobile phones, there is a widespread public concern that EMF may have potential harmful effects [21]. As the mobile phones are usually held close to the ear, users often complain of a burning or heating sensation within the auricle area. The increase in temperature during MP use may be due to electric power dissipation and radio frequency (RF) exposure [22]. Several reports indicated that non-thermal electromagnetic radiation such as from mobile phones and base stations may promote cancer [23].

\section{Adverse effects of excessive mobile phone use}

Cell phone radiation puts certain populations at a higher risk of harmful health consequences than others. Radio Frequency (RF) waves are radiofrequency waves, and are forms of energy in the electromagnetic spectrum. RF waves are most often used for means of telecommunication and can actually be absorbed by the human body. RF energy, when absorbed by the body, is measured according to the Specific Absorption Rate (SAR), or the measure of which energy is absorbed by the body when exposed to a radio frequency [24]. The SAR is established to ensure the safety of individuals against excessive RF exposure, which can be harmful due to the ability of RF energy to rapidly heat biological tissue. Severe RF exposure has the potential to lead to "tissue damage in humans because of the body's inability to cope with or dissipate the excessive heat that could be generated.

Pregnant women, specifically their unborn children, and young children and adolescents are at a higher risk with cell phone radiation exposure. Rural cell phone users generally experience higher radiation from their cell phones, as cellular towers may not be located as closely as cell phone users in more urban areas. When cellular towers are located further away, your cell phone must work harder to send and receive signal [25]. This additional work puts off more radiation than does a phone with a healthy signal. In fact, the power bars on your phone give you an indication of how much radiation you are being exposed to during a call--the fewer number of bars, the greater amount of radiation [25].

However, of all these at-risk populations, young children and adolescents are at the forefront for potential risk. Cell phone radiation exposure on young children and adolescents is and will be the most widespread. This is due to the exposure of young children and adolescents to cell phone radiation from an early age with a lifetime of cell phone use ahead of them. With a lifetime of use, young children and adolescents are opened up to any and all of the potentially harmful health risks associated with the proximity of cell phones, as well as the extent of their use over the decades. Children and adolescents are not yet fully developed, meaning that cell phone radiation penetrates much more easily and fully into their bodies [26]. Young children are at a much higher risk for radiation penetration. The problem with this situation lies in the fact that children's skulls are thinner and their brains are less dense so there's more absorption of radio frequency signals [27]. Interestingly, many cell phone applications are made specifically for children's use of smart phones. While the games may be educational and entertaining, children are learning earlier and earlier the widespread normalcy of cell phone use. The earlier children are taught to use cell phones, the more potential danger exists for that child's future.

Another study was designed to investigate whether the symptoms of ill health reported by young people may be associated with the use of mobile phone (MP) and to analyse its influence on health and development of medical students. The conclusion of the study indicated that mobile phones play a large part in the daily life of students, urging that the psychology and health situation be should be discussed among the students to prevent the harmful effects of mobile phone use [27]. Another study on teens revealed that there are physical, cognitive and social health implications of mobile phone use in young users [28].

Exposure to radiation from cell phones may also play a role for a growing spate of serious problems, including attention and hearing deficits, autism, behavioural changes, insomnia, ringing of the ears or tinnitus, Parkinson's, Alzheimer's and a broad array of disturbances to the nervous system. Some of the effects of cell phone radiation include an increase in glucose in the brain, a process that 'occurs with infections and other inflammatory processes, and leads to the production of potentially damaging reactive oxygen radicals that can alter the ways that cells and genes work' [29]. This cell phone radiation can lead to tissue dysfunction such as leakage in the protective blood brain barrier and genetic damage, including interference with deoxyribonucleic acid (DNA) repair. These biological effects lead to conditions ranging from brain tumours, to learning difficulties in children. Other studies have concluded that cell phones radiate heat to the ear, eye and brain, which if too severe, could damage the tissue.

Further, cell phone antennas generate signals, radiation waves that are similar to those produced by our bodies' own electrical systems. These waves of radiation seem to create confusion within our own systems, causing our bodies' defensive systems to activate through a process of protective biochemical reactions that alter physiology and cause biological problems that include intracellular free radical build-up, leakage in the blood-brain barrier, genetic damage, disruption of intercellular communication, and an increase in the risk of tumours [30]. According, the danger of radiation is not from "direct damage, but 
rather due to the biochemical responses in the cell. In other words, cell phones affect the human body physically, but not in such a way that cellular heat alone produces cancerous cells. Rather, cell phone radiation spurs the body's natural defence mechanisms, whose reactions open the body up to an increased risk of cancer development. It is worth noting also that sperm count and sperm health lessened greatly the more a cell phone was used, while with less cell phone use, men produced higher sperm count, and higher quality semen. Results seem to suggest that prolonged exposure to cell phone radiation may have negative effects on sperm motility [31].

The prevalence of cell phone exposure can be combated through many different means. Exposure to this radiation, whether the risks are more or less real than believed, can be reduced. These techniques do not promise complete protection from cell phone radiation exposure, nor do they promise to eliminate the harmful consequences of such exposure. These techniques are merely a means to reduce such risks. Don't hold a cell phone directly up to your head. Use a headset or speakerphone to talk on the phone; pregnant women should keep cell phones away from their abdomen and men who wish to become fathers should never keep phones on in their pocket; don't allow children to play with or use your cell phone. Older children should use a headset when talking on a cell phone; Turn off your wireless router at night to minimize exposure to radiation; Eat green vegetables and get a good night's sleep in a dark room to enhance natural repair of DNA that may have been damaged by radiation; Never, ever put a cell phone up to the ear of a baby; Limit your child's use of a cell phone to essential purposes only and keep the calls short; It's best to keep your cell phone away from your body - do not clip it on your belt or put it in your pocket. Instead put it in your purse or backpack; Before making a call check the number of bars that indicate reception - a good signal means that the phone is using less radiation to transmit; Charging your phone creates a high level of radiation, so charge it in another room; Switch ears regularly, distributing radiation more evenly; Don't sleep near your cell phone etc.

While many of the techniques listed above seem to be common sense, it is surprising how many people can be seen in such practices. These actions have likely become habitual, and practices like remembering to charge your cell phone in a place other than next to your pillow may prove difficult, not to mention inconvenient. On a further note, the regulatory responsibilities of the regulators does not touch on most of the aspects mentioned above, including the certification of all phones that are sold in Cameroon to comply with guidelines on radiofrequency exposure.

Further, public health authorities have to assume responsibility and bring awareness to the public.
By alerting the public to the safety of cell phones due to regulations, as well as the risks associated with the radiation exposure, the consumer will be free to decide which precautions to take, if any. Above all, public health authorities need to bring the public awareness on the potential dangers our most at-risk populations face.

\section{Telemedicine}

Telemedicine has a long history, since 500BC, but evolved in the 19th century with the invention of electricity and radio, and in the 20th century with the development of television and the Internet [32]. The use of telemedicine is driven both by consumers, who seek to take advantage of technologies that can improve their health and quality of life, and by healthcare systems, which are interested in providing quality services with a reduced budget. The use of the mobile telecommunication system is fundamental in this regard. Recent technological advances have occurred to the extent that Healthcare may be possible in the near future by using big health data analytics and artificial intelligence. Today, fast Internet connections are widespread, through both fibre-optic and mobile networks (4G/5G), allowing for synchronous, uninterrupted video streaming (which is necessary in many telemedicine applications). All smart phones sold by major market players are equipped with a free application that can monitor the user's physical activity [32].

In this respect, mobile communication is inevitable to the deployment of telemedicine to the whole population of a country, which largely depends on the level of digitalisation, including the digital skills of patients and health professionals, as well as the legislation governing the sharing and processing of health data. The issue here is the promotion of mHealth and eHealth for the promotion of health care of the country. The World Health Organisation (WHO) defines eHealth as the use of information and communication technologies (ICT) for health. The terms 'eHealth' (electronic health) and 'mHealth' (mobile health) have been used in recent years to describe the provision of health services using the Internet and mobile devices, respectively [33].

It is important to establish a distinction between telemedicine and telehealth. According to the WHO, telehealth involves the use of telecommunications and virtual technology to deliver health care outside of traditional health-care facilities, for example, a virtual home health care, where patients such as the chronically ill or the elderly may receive guidance in certain procedures while remaining at home [34]. Telehealth has also made it easier for health care workers in remote field settings to obtain guidance from professionals elsewhere in diagnosis, care and referral of patients. Telehealth, is further referred to as the use of electronic information and telecommunications technologies to support long-distance clinical health 
care, patient and professional health related education, public health, and health administration. To establish such distinction, it is suggested that telehealth refers to both clinical and non-clinical applications in the way of education, administration, and research while telemedicine is often reserved for clinical, patient care applications [35].

There is a need for policy makers to undertaken a number of successful initiatives to facilitate telemedicine adoption. Additional interventions that would support wider deployment and uptake of telemedicine include: raising public awareness about the benefits of telemedicine, supporting large-scale projects where telemedicine can be tested and its benefits assessed, as well as legislative interventions by the government to address some of the barriers for telemedicine adoption in Cameroon [32].

\section{Regulatory and Policy Considerations}

The absence of a national-level strategy for telemedicine is unusual but observed Cameroon. The government of Cameroon does not feel the urgency to develop telemedicine and do not consider it a high priority of health strategic direction. This justifies why she lacks a precise legal framework to regulate telemedicine practices. Thus, it is important for decision-makers to undertake reforms of the current laws in order to promote telemedicine as this will also will encourage the local market [36].

\section{Interoperability - Lack of standards and guidelines}

The lack of widely accepted/adopted standards and procedures represents a further obstacle about telemedicine. It limits trust in the quality and reliability of telemedicine solutions. Within and across countries, telemedicine practices are not necessarily standardised and thus not necessarily compatible. Thus, such an initiative should be taken into consideration by the telemedicine market stakeholder even if these guidelines are optional.

Also, special attention should be directed to the regime of medical liability or the standard of care for healthcare providers. It brings about a serious issue of interoperability between telemedicine solutions. Interoperability is fundamental to avoid legal obstacles (various telemedicine laws), operational obstacles (various methods for data collection) or language obstacles (various terminology or translation issues) [32]. Through the eHealth Action Plan 2012-2020, the European Commission aims to support patients and healthcare workers, to connect devices and technologies, and to invest in making medicine more personalised. In particular, by capitalising on tablet and smartphone technology (mhealth) the Action Plan seeks to ensure the provision of smarter, safer and patientcentred health services in the future [37].

\section{Data Security}

This lack of standards has mostly been felt in relation to data ownership and data sharing. Indeed, countries have been struggling to implement regulations or requirements related to cross-border sharing of patient data. Because of the legal vacuum regarding data protection and security in most countries, many fear a commercial or malicious use of patient data. Determining the right of access to patient information is a difficult question to solve. How much patient information should be made available to hospitals? Legal loopholes are persisting on these issues and responsibilities are not clearly defined. All these concerns represent a major barrier to patients' acceptance of telemedicine [32].

\section{Liability Issues}

Due to the number of stakeholders involved and the complexity of the systems and workflows, delivery risk for eHealth projects is relatively high [33]. Legislations are not clear regarding liability and accountability of practitioners in telemedicine. Therefore, physicians are reluctant to embrace telemedicine since they are worried about being made responsible for failing to act. For instance, a telemonitoring device such as Life Watch transmits wirelessly and continuously asymptotic and symptomatic arrhythmia to clinicians. If the doctor is busy and does not have time to review the patient's daily activity, he/she might not notice the patient's condition worsening. If the patient passes away, would the doctor be made responsible for held liable? The legal framework in Cameroon does not provide explicit rules about liability. This will obviously make it fearful, because of lack of regulation, for healthcare professionals to use telemedicine, because they deem that the nature of remote or virtual care exposes them to the risk of malpractice. Given the nature of medical liability (which depends on the scope of the system in question), eHealth implementations also have the potential for large financial and brand risk that is of particular concern to mobile operators, who take great care with their consumer brand. How these opportunities and challenges play out depend largely on their appetite for risk and local market conditions, which will impact what sort of position the mobile operator, might wish to take within that particular market [33].

\section{The Benefits of Mobile Telecommunication Sector}

The American and European societies are much richer today than they were 100 years ago, yet they are also vastly more regulated. Today, we live in houses and apartment buildings whose construction from zoning, to use of materials, to fire codes - is heavily regulated. We eat food grown with heavily regulated fertilizers and hormones, processed in heavily regulated factories with publicly monitored technologies, and sold in heavily regulated outlets with elaborate labels and warnings. Our means of transport, 
including cars, buses, and airplanes, are made, sold, driven, and maintained under heavy government regulation. Our children attend schools that teach heavily regulated curricula, visit doctors following heavily regulated procedures and paid governmentcontrolled prices, and play on play-grounds using government-mandated safety standards [38].

The extraordinary pervasiveness of government regulation in our lives raises number of questions. Is regulation generally a good idea, as the positive correlation between its growth and the growth of income seems to indicate, or has it been an obstacle to economic and social progress? Have the USA and Western Europe grown in spite of it? How much regulation of a particular activity is appropriate? Does the nature of the activity being regulated, or the characteristics of a country, influence the optimal choice? Is the level of regulation we observe in fact an outcome of efficient social choice, or are other factors as or more important [39]?

After identifying those approaches and regulations that have proven successful and those wanting in the areas of competition, consumer protection, interconnection, licensing, universal service coverage, numbering, spectrum regulation, infrastructure sharing in the telecommunications sector, there is therefore the need to access such benefits. General opinion holds that effective regulation result in greater economic growth, increased investment, lower prices, and better quality of service, higher penetration, and more rapid technological innovation in the sector.

\section{An impressive Deployment of Infrastructure}

Indeed, thanks to the combined dynamism of the local public authorities and leading companies in telecommunications operating in the country, Cameroon has become the main landing point, in Central Africa, of several submarine optic fibre cables, critical infrastructure in the development of telecommunication services. Indeed, after SAT, first submarine cable deployed in Cameroon by the State, through the historical telecommunication operator Camtel; WACS, deployed by MTN Cameroun then handed over to the State in compliance with the current law in the country, has been operational since July 2015 [40]. While awaiting the completion of the works for the construction and commissioning of the landing point of the submarine cable ACE (Africa Coast to Europe), a project implemented by the local subsidiary of the Orange group, Cameroon welcomed in December 2015 a new submarine cable. This is NCNCS, deployed between Cameroon and Nigeria by the consortium Main One, in which the State of Cameroon is an active participant.

Soon, a 5th submarine cable will land in the country. This is the South Atlantic Inter Link, which will be the first structure of this type to link Africa to the American continent, as it will be rolled out between the towns of Fortaleza, Brazil and Kribi, Cameroon. The project is spearheaded by a consortium gathering Cameroon Telecommunications (Camtel) and China Unicom, a branch of the national Chinese telecoms operator, China Telecom, specialised in mobile telephony.

All these investments, on-going or completed, today enable Cameroon to have an urban and interurban optic fibre network estimated at roughly 6,000 kilometres, which should be increased to 10,000 kilometres by 2020, according to the forecasts of the government. Ambitions and performances which have transformed Cameroon into a mirror for countries such as Chad and Burkina Faso, whose experts have come to get inspiration from the Cameroonian experience in terms of deployment of optic fibre [41].

\section{Increased Investment}

Liberalisation in the telecommunications sector is greatly encouraged by World Trade Organisation (WTO) commitments and obligations, particularly the WTO Reference Paper on regulatory principles. Early evidence of the impact of liberalisation under the WTO's Basic Telecommunication Agreement (BTA) in low income Sub-Saharan African countries shows that growth in telecommunications revenues as a percentage of GDP is higher in countries that have made GATS commitments in telecommunications [41]. Thus, investors are likely to be more willing to commit capital and technology in countries with WTO telecommunications commitments, as they are likely to be rewarded with higher revenues. Cameroon, for example, reformed its telecommunications sector and now enjoys healthy revenue growth. The law $n^{\circ} 98 /$ 014 of 14 July 1998 to govern Telecommunications in Cameroon is instrumental here.

Cameroon understood how important effective regulation was to attract foreign investment to developing economies as it began laying the groundwork for privatisation and liberalisation of its telecommunication market in the late 1990s. Also Law $\mathrm{n}^{\circ} 98$ / 014 of 14 July 1998 to govern Telecommunications in Cameroon provided for the independent regulator, the Telecommunications Regulation Board (TRB). Decree No.98/197/R of September 8, 1998 laying Down the Organisation and Functioning of the Telecommunications Regulatory Board, further consolidated its creation. By designing its vision for a liberalised market in a clear and transparent way, the Cameroonian framework inspired investor confidence, which was reflected in the country's privatisation process in the ICT sector.

There is a need to strengthen the supply electric current, decrease the costs of communication and Internet access, face new challenges related to labour rights and social security protection, and the 
finding the mechanism to finance entrepreneurial initiatives. Moreover, the simplification of procedures must be strengthened to enable the creation of businesses based on ICT. It is crucial that the government finds ways to regulate the economy in order to provide better benefits in terms of employment. Thus significant investments are currently being made in creating an enabling environment for this to take effect, ranging from wide infrastructure development, development of the energy sector and policy development to enhance services in the sector, ensuring that citizens access and generate knowledge to transform the country's economy. According to the Annual Observatory of Cameroon's TRB, investments in 2016 stood at 398,63 billion FCFA recoding a $34.04 \%$ increase from the 2015 figures and there has been an increase in government investment in the sector since 2010, as a quest to meet network coverage across the national territory improving quality of services (QoS) of electronic communication to users [42].

\begin{tabular}{|r|r|}
\hline \% GDP & $3.4 \%$ \\
\hline Investment(ICT) (Billion CFA) & 700 \\
\hline Income (State) (Billion CFA) & 195 \\
\hline Direct Jobs & 6000 \\
\hline Indirect Jobs & 500.000 \\
\hline
\end{tabular}

Source: Cameroons investments in ICTs. 2017 TRB data

It is, therefore, obvious that competition, brought about by liberalization in the telecommunications sector, is the most effective driver for sector performance. Investors consider the regulatory environment to be a critical factor in their analysis of whether or not to invest in a country. They often have a set of regulatory conditions that must be present for them to consider an investment in a particular country. A report presented at the ITU's 2002 Global Symposium for Regulators summarizes several key findings from the private sector on this issue:

- Regulatory issues are a key factor in market entry and expansion decisions;

- Interactions between regulators and operators are most challenging during times of transition;

- Companies look at the overall regulatory environment - not just specific regulations.

- Transparency and responsiveness are important factors in the willingness of companies to enter and stay in markets;

- Companies employ a variety of ways to ensure that regulatory information is factored into business planning and decision-making [39].

The conclusion is that there is a link between good regulation and the amount of investment attracted into a country. Even if the overall investment in the sector is still low despite the potential of the telecommunication services, the sector plays an important role in the economy in terms of investment, revenue and employment [43].

\section{Job creation/employment and remuneration}

From the statistical data provided by the Regulator in 2004 it can be assessed that the contribution of the telecommunications sector to national employment has risen as the sector continues to grow. This is as a result of the policy expansion of the mobile industry; the liberalisation of the provision of access services through call boxes, telephone booths and internet cafés. The training sector has also generated jobs to develop the skills needed to service the sector [43].

The sector is considered as one of the best-paid in terms of salary and revenue. On average, a manager in the telecoms sector earns twice the salary of his colleague in education or health. The sector currently provides over 15000 jobs. The majority of these jobs come from the informal sector, the call boxes. The call boxes are a source of self-managed informal economic activity that has generated more than 10000 jobs between 2002 and 2004. They are proportionally distributed between metropolitan urban areas and rural areas. Women are most employed in this segment of the market.

\section{Economic Growth and Consumer Benefits}

The last 13 years have witnessed an era of initiatives to develop and harness the benefits of ICT for the nation's development [44]. The 1998 laws [45] provide the legal backing for ICT evolution in Cameroon. These laws brought an end to monopoly control in the telecommunication sector in Cameroon. They gave birth to telecoms liberalization and privatization, ushering in new players in telecommunications and encouraging investment in ICT. Further progress in legislation was made in 2001, instituting minimum service standards in the telecommunications sector through a series of decrees laying down the modalities for the operation of telecommunications networks and the provision of telecommunications services [46]. These developments led to an opening up of citizens' and business demand for ICT availability [44].

The importance of affording protection for the consumer has been accorded global recognition. This informed the decision of the United Nations to come up with a guideline for consumer protection as far back as 1985. The UN Guideline for consumer protection was adopted by the General Assembly on $9^{\text {th }}$ April 1985 and was amended in 1999. The Guideline serves as a model for governments to follow; thus, enabling them to formulate legislations and policies, which would address consumer, concerns and protect their interests. In this respect, the UN Guideline for consumer protection recognizes the following as legitimate rights of the consumer, which must be guaranteed by 
governments. Right to satisfaction of basic needs, Right to safety, Right to choice, Right to information, Right to consumer education, Right to redress, Right to representation, and Right to a healthy environment.

Countries that make significant strides towards pro-competitive regulation, in return achieved considerable progress in bridging the digital divide. After making comprehensive reforms in the telecommunication sector, with respect to the regulatory framework to promote technological neutrality and taking advantage of the ex post regulation, growth in investment is inevitable. The result is always economic growth and marked increases in the mobile telephony subscribers and a fall in mobile tariffs.

\section{Growth of New Services}

Competitive mobile markets typically show higher penetration rates than those that have not been liberalized. Due to the harsh competition in the market, telecom operators are always at a haste to make their offers attractive and attract many customers. The high level of prospection and the degree of increased value added services is fundamental in this respect. These new services are supplementary services obtainable from telecommunications operators, which come to add to the basic services provided by them, with specific conditions. These services are numerous, including customer services, radio, voice messages, mobile money, mobile banking e-learning, e-banking, ebusiness, Skype etc. These services add considerably to the national economy. Data from the TRB shows that in 2016, these services raised revenue amounting to 259 484863 FCFA, with an increase of 34, 7\% in 2015.

\section{Lower Prices for Consumers}

Lower prices for international telephone calls, for example, are also highly correlated with the level of competition. In Cameroon for instance, the cost of national calls have been regulated to lower rate, due to the regulation in the interconnection prices. International calls have drop drastically, thanks to the very special offers made by these operators. MTN Roaming for example, has the Hello World bundle, which permit users to optimise their airtime. These extend to prises of basic ICT equipment for telecommunication purposes. MTN has the MTN-Wi$\mathrm{Fi}$, which serve to advertise attractive offers at the market.

\section{Gambling Syndrome}

Regulators must often intervene to remedy shortcomings in competition and ensure that competition is working effectively, which sometimes includes imposing some form of regulation. The overlyfreewheeling nature of the mobile sector at present is threatening some of the gains made in the sector's earlier development stages. Loopholes in regulation have enabled mobile operators to enter the gambling industry, thus potentially contributing to poverty and family dysfunction in the country.

\section{CONCLUSION}

Given the ever advancement in technology, the telecommunications sector is one of ever changing environment, warranting continuing legislation. A mastery of the regulatory environment to meet the challenges, both of a logical and empirical nature, has to do with market drivers and conflict of interest, which equally is a factor inherent in the emerging telecommunications market. Balancing the needs of both consumers and operators are most often fostered by the benefits to be attained. Note, however that the benefits of these telecommunications companies to the economy of the country, tells much about the situation of consumers in third world countries, where economic drivers far outweigh the common good.

From the above discussion, we therefore, recommend among others, that the government should revisit laws on mobile telecommunication sector in Cameroon. They should specifically harmonize and overhaul flawed mobile telecommunication legislation with clear, precise and simple language for better comprehension. The government should also strengthen institutional capacity to enhance effective compliance with mobile telecommunication regulations, to attain economic sustainability goal.Training of law enforcement officers is further necessary to introduce training initiatives to help fight against corruption and mobile telecoms regulation offences, in order to deliver secure and effective mobile telecom services.

\section{REFERENCES}

1. Mbodiam, B. R. (2017). 'From 3G to 4G?' Business in Cameroon, Magazine, No.15:9.

2. Blackman, C., \& Srivastava, L. (Eds). (2010). Op. Cit., 5.

3. Posu, S. M. A. (2006). Information and Communication Technologies in the Nigerian Economy. International Conference on Human and Economic Resources Izmir Technology, 334.

4. Yossi, R. N. (2012). The challenge of cyber power for central African countries: risks and opportunities. NAVAL POSTGRADUATE SCHOOL MONTEREY CA.

5. Republic of Cameroon, 'Télécommunications et TIC: Bilan du septennat des grandes ambitions.

6. Ebongue, J. L. (2015). 'Rethinking Network Connectivity in Rural Communities in Cameroon', University of Ngaoundéré, Ngaoundéré, Cameroon.

7. For more information, see the Civil Cabinet, Presidency of the Republic (2016). 'The Time for Investors: Digital Economy', Civil Cabinet, Presidency of the republic of Cameroon. Available at http://www.conferenceinvestiraucameroun.com/co 
nfcameroun-

content/uploads/2015/06/Letempsdesinvestisseurs _EconomieNum\%C3\%A9rique.pdf. (Accessed on June 15, 2017).

8. Etoundi, R. A., Onana, F. S. M., Olle, G. D. O., \& Eteme, A. A. (2016). Development of the digital economy in cameroon: challenges and perspectives. The Electronic Journal of Information Systems in Developing Countries, 76(1), 1-24.

9. Turban, E., Leidner, D., McLean, E., Wetherbe, J., \& Cheung, C. (2007). Information Technology for Management: Transforming Organizations in the Digital Economy, John Wiley \& Sons, Inc. New York, NY, USA.

10. Arthur, W. B. (2011), 'The Second Economy', McKinsey Quarterly. Available at http://www.mckinsey.com/business-

functions/strategy-and-corporate-

finance/ourinsights/the-second-

economy.(Accessed on July 30, 2016).

11. Britton, D. B., \& McGonegal, S. (2007). The Digital Economy Fact Book, the Progress \& Freedom Foundation, Ninth Edition.

12. ITU, (nd).Green ICT Standards: A Path to Environmental Sustainability, for more information on ITU-T's ICTs, Environment and Climate Change activities can be found at: www.itu.int/ITU-T/climatechange/ 14.

13. GSMA. Environmental Impact of Mobile Communications Networks, Mobile Technology, Health and the Environment, GSMA website: www.gsmworld.com/environment.

14. The Global e-Sustainability Initiative estimates that in 2002, the mobile industry composed about $43 \%$ of the global information and communications technology (ICT) energy related emissions and this could rise to $51 \%$ by 2020 . See generally SMART 2020. (2008). 'Enabling the low carbon economy in the information age', report by The Climate Group on behalf of the Global e-Sustainability Initiative.

15. Technology evolution has delivered greater capacity, about an 8 fold increase between the original analogue services and $3 \mathrm{G}$. This has been accompanied by improvements in equipment efficiency, with a 3 fold increase in the efficiency for $3 \mathrm{G}$ base station amplifiers between 2001 and 2007.

16. $125 \mathrm{~km}$ per 10.5 litres of petrol. See GSMA. Environmental Impact of Mobile Communications Networks, Mobile Technology, Health and the Environment, GSMA website: www.gsmworld.com/environment.

17. A common source of ionizing radiation is radioactive materials that emit $\alpha$ (Alpha), $\beta$ Beta), or $\gamma$ (Gamma) radiation. In general, ionizing radiation is harmful and potentially lethal to living beings but can have health benefits in radiation therapy for the treatment of cancer and some thyroid diseases.

18. Nigerian Communications Commission (NCC). (nd). Health implication of the mounting of telecommunications mast close to buildings, Presentation to the House of Representatives. AdHoc Committee to Investigate the Health Implication of the Mounting of Telecommunications Mast Close to Buildings, NCC. P. 15.

19. WHO Online Q \& A September 2013, and WHO Backgrounder 2006, Cited in Nigerian Communications Commission (NCC). (nd). Health Implication Of The Mounting Of Telecommunications Mast Close To Buildings, Presentation to the House of Representatives AdHoc Committee to Investigate the Health Implication of the Mounting of Telecommunications Mast Close to Buildings, NCC, 26.

20. Ghauri M. R. (2013). 'How to Go Green as a Telecommunication Company in a Global Market,' Upsala University, Master Thesis E, in Sustainable Development, 14.

21. Khan, M. M. (2008). Adverse Effects of Excessive Mobile Phone Use. International Journal of Occupational Medicine and Environmental Health, 21(4):289-293.

22. Straume, A., Oftedal G., \& Johnson, A. (2005). Skin temperature increase caused by a mobile phone: a methodological infrared camera study. Bio electromagnetics, 26(6):510-519.

23. Sommer, A. M., Streckert, J., Bitz, A. K., Hansen, V. W., \& Lerchl, A. (2004). No effects of GSMmodulated $900 \mathrm{MHz}$ electromagnetic fields on survival rate and spontaneous development of lymphoma in female AKR/J mice. $B M C$ cancer, 4(1), 1-13.

24. Classic, K. (2011). Radiofrequency $(R F)$ radiation. Health physics society.

25. Fosburg, M. (2006). 'Health effects of electromagnetic radiation', Total Health, 28(1).

26. Pritchard, L. M. (2012). 'Cell Phone Radiation Exposure and Regulation', Research Papers. Paper 299, Southern Illinois University Carbondale, 15.

27. Greer, B. (2010). Are cell phones safe? How to avoid risk. Washington Times Communities. Cited in Pritchard, L. M. (2012). 'Cell Phone Radiation Exposure and Regulation', Research Papers. Paper 299, Southern Illinois University Carbondale, p.16.

28. See Fowler J. \& Noyes J. (2017). 'A study of the health implications of mobile phone use in 8-14s', DYNA, vol. 84, No.200, pp.228-233.

29. Davis Cited in Pritchard L. M. (2012). 'Cell Phone Radiation Exposure and Regulation', Research Papers. Paper 299, Southern Illinois University Carbondale, 5.

30. Kovach, 2007, Cited in Pritchard, L. M. (2012). 'Cell Phone Radiation Exposure and Regulation', 
Research Papers. Paper 299, Southern Illinois University Carbondale, 7.

31. Ferguson, 2011, Cited in Pritchard L. M. (2012). 'Cell Phone Radiation Exposure and Regulation', Research Papers. Paper 299, Southern Illinois University Carbondale, 12.

32. European commission (EC). (2018). 'Market Study on telemedicine', Third EU Health Programme, Final Report, 20.

33. Foh K. L. (2012). Integrating Healthcare: The Role and Value of Mobile Operators in eHealth, GSMA mHealth programme, 4.

34. Available at http://www.who.int/sustainabledevelopment/health-sector/strategies/telehealth/en/ (Accessed on 19 December 2019).

35. Miller, E. A. (2007). Solving the disjuncture between research and practice: Telehealth trends in the $21^{\text {st }}$ century. Health Policy, 82:133-141.

36. For instance, in Switzerland, the government enacted a law in April 2017 to adopt interoperable patients' electronic health records (EHRs) and thus paved the way to its broad adoption.

37. Available at https: //ec.europa.eu/digital-singlemarket/en/news/ehealth-action-plan-2012-2020innovative-healthcare-21st-century. (Accessed on 15 December 2019).

38. Shleifer, A. (2005). Understanding Regulation, Blackwell Publishing Ltd, 18.
39. ITU, ICT Regulation Toolkit, Module 6. Legal and Institutional Framework, 10.

40. Nana, O., \& Tankeu, R. (2012). 'Understanding what is happening in ICT in Cameroon; A supplyand demand side analysis of the ICT sector', in Evidence for ICT Policy Action, Policy Paper 2.

41. Mbodiam, B. R. (2017). 'From 3G to 4G?' Business in Cameroon, Magazine, 15:9.

42. Mboumien, N. E. N. (2018). Assessing The SocioEconomic Impact of Internet Shutdown in the English Speaking Regions of Cameroon from a Multistakeholder and Multisector Perspective, AfroLeadership, Internews, 3.

43. Nzepa, O. N., \& Keutchankeu, R. T. (nd). (2007). Cameroon Telecommunications Sector Performance Review: a supply side analysis of policy outcomes', Research ICT Africa (RIA), 29.

44. Asongwe, P. N. (2012). The Government and the Cameroon Cyber security Legislation 2010: Opportunities and Challenges. The African Journal of Information and Communication Issues, 12:157.

45. Telecommunications Law No. 98/014 of 13 July 1998 and Telecommunications Law No. 98/014 of 14 July 1998.

46. Law no $98 / 014$ of 14 July 1998 to govern telecommunication in Cameroon modified and completed by law no 2005/013 of 29 December 2005 . 